\title{
CLÁUSULA DE EXCLUSÃO POR COMETIMENTO DE CRIME HEDIONDO, ATOS TERRORISTAS E DE TRÁFICO DE DROGAS DA CONDIÇÁO DE REFUGIADO: A INTERVENÇÁO INDEVIDA DO DIREITO PENAL NOS DIREITOS HUMANOS
}

\author{
EXCLUSION CLAUSE FOR HEINOUS CRIME, TERRORIST ACTS AND DRUG TRAFFICKING \\ FROM REFUGEE STATUS: IMPROPER INTERVENTION OF CRIMINAL LAW IN HUMAN RIGHTS
}

Daniela Corrêa Jacques Brauner

Doutora em Direito pela Universidade Federal do Rio Grande do Sul Defensora Pública Federal, DPU/RS

daniela.jacques@dpu.def.br

\section{RESUMO}

$\mathrm{O}$ aumento do número de refugiados no mundo hoje tem evidenciado uma crise de imigração com a procura de novos lares por milhares de pessoas que se qualificam como refugiados. No Brasil, o regime jurídico foi estabelecido pela Lei 9.474 que consigna uma definição ampliada do conceito de refugiados logo em seu artigo $1^{\circ}$. A referida legislação foi adotada tendo em vista a adesão ao Brasil à Convenção das Naçóes Unidas relativa ao Estatuto dos Refugiados de 1951. No entanto, a legislação nacional apresenta novas hipóteses de exclusão em relação ao cometimento de crimes hediondos, atos terroristas e tráfico de drogas, sem igual previsão no principal tratado internacional sobre o tema. O desenvolvimento do estudo sobre a temática irá evidenciar que a cláusula de exclusão contida no art. $3^{\circ}$ da Lei $n^{\circ} 9.474$ revela uma interferência de política criminal que viola a proteção internacional dos direitos humanos. A análise a respeito do cometimento dos delitos apontados poderá descaracterizar a condição jurídica de refugiado instrumentalizada na referida Convenção, com expressa violação ao princípio do nonrefoulement. Admitindo-se a natureza de Direitos Humanos ao Direito dos Refugiados, a sua proteçáo não pode estar condicionada à interferência da política criminal nacional, cada vez mais acentuada e discriminatória dos indivíduos, pois o respeito aos direitos humanos tem aplicação universal e incondicional. As considerações sobre a interferência do Direito Penal no conceito de refugiado, revela enfraquecimento da proteção dos direitos humanos a que o Brasil se comprometeu no âmbito do direito internacional.

Palavras-chave: Refugiados. Cláusula de Exclusão. Direito Penal. Direitos Humanos. 


\begin{abstract}
The increase in the number of refugees in the world today has evidenced an immigration crisis: thousands of people as refugees searching for new homes. In Brazil, the legal regime was established by Statute 9.474, which enlarges the definition of refugees (article 1). However, the legislation presents new possibilities of exclusion due to heinous crime committed, terrorist acts and drug trafficking, without specific provision in the Convention of 51. The study will show that the exclusion clause in the Statute 9497, art. 3 discloses a criminal policy interference that violates the international protection of human rights. The crime analysis by the exclusion clause can violate the refugee's institute that is established in Human Rights International Conventions, especially de non-refoulement principle. Considering the international refugee protection as part of the human rights, it can not be conditioned to the interference of the national criminal policy. We may conclude that the interference of criminal law in the concept of refugee reveals a weakness of the protection of human rights to which Brazil has committed itself under international treaties.
\end{abstract}

Keywords: Refugees. Exclusion Clause. Criminal Law. Humans Rights.

Dara de submissão: 10/07/2018

Data de aceitação: 12.07.2019

\title{
SUMÁRIO
}

INTRODUÇÃO 1. DO ART. 3 DA LEI No 9.474 - “(...) CRIME HEDIONDO, ATOS TERRORISTASS E TRÁFICO DE DROGAS”. 2. O DIREITO DOS REFUGIADOS COMO PARTE DOS DIREITOS HUMANOS. CONSIDERAÇÓES FINAIS

\section{INTRODUÇÁO}

O tema dos refugiados apresenta-se cada vez mais presente no cenário internacional. ${ }^{1}$ Esse crescimento, ao contrário do prognóstico esperado quando da publicação da Convenção Relativa ao Estatuto dos Refugiados (Convenção de 51), reascende, no mundo, a necessidade de se discutir o próprio conceito de refugiado, merecedor de tutela protetiva dos Estados nacionais.

Logo em seu artigo $1^{\circ}$, a Convenção de 51 trata do termo refugiado e os limites de sua

1 A ONU considera a prior crise humanitária do século. Vide: https://nacoesunidas.org/acao/ refugiados/. 
aplicação. Observa-se que o seu conceito é bastante abrangente e há especial preocupação em tutelar os refugiados dos conflitos armados ocorridos anteriormente à década de 1950 , sobretudo em razão da II Grande Guerra. ${ }^{2}$ Considera-se refugiado:

qualquer pessoa que, em consequência dos acontecimentos ocorridos antes de $1^{\circ}$ de janeiro de 1951 e temendo ser perseguida por motivos de raça, religião, nacionalidade, grupo social ou opinióes políticas, se encontra fora do país de sua nacionalidade e que não pode ou, em virtude desse temor, não quer valer-se da proteção desse país, ou que, se não tem nacionalidade e se encontra fora do país no qual tinha sua residência habitual em conseqüência de tais acontecimentos, não pode ou, devido ao referido temor, não quer voltar a ele.

A extensão do conceito de refugiado, independentemente da data limite de 01/01/1951 e sem nenhuma delimitação geográfica, ocorreu a partir do Protocolo Relativo ao Estatuto dos Refugiados (Protocolo de 67), que alterou a Convenção de 51 para os Estados que o aceitaram. Há previsão, na própria Convenção, de hipóteses de não-aplicação, quando diz respeito à nacionalidade e à proteção de seu país de origem ${ }^{3}$ ou, ainda, no caso de suspeitas de que o requerente de refúgio tenha praticado crime de guerra ou contra a humanidade, ou ainda crime grave de direito comum fora do país de refúgio e antes de ser admitido como refugiado ou atos contrários aos fins e princípios da ONU. ${ }^{4}$

O Brasil torna-se parte da Convenção de 51 a partir de 28/01/1961, quando publica o Decreto 50.215 e em 8/08/1972 do Protocolo de 67 quando este passa a vigorar pela publicaçáo do Decreto 70.946. A implementação efetiva da proteçáo dos refugiados, todavia, somente se deu com a edição da Lei 9.474/97 com a previsão de políticas públicas para essa área e a criação de um órgão, no âmbito da administração pública, responsável pela elegibilidade dos casos individuais - Comitê Nacional para Refugiados (Conare)-, órgão vinculado ao Ministério da Justiça. ${ }^{5}$

A Lei 9.474 expressamente consigna a definição ampliada do conceito de refugiados logo

2 Vide JAEGER, G. On the History of the International Protection of Refugees. International Review of the Red Cross, Setembro 2001. Disponível em: <https://www.icrc.org/ara/assets/files/other/727_738_ jaeger.pdfs.

3 "C. Esta Convenção cessará, nos casos abaixo, de ser aplicável a qualquer pessoa compreendida nos termos da seção A, acima - 1) se ela voltou a valer-se da proteção do país de que é nacional; ou 2) se havendo perdido a nacionalidade, ela a recuperou voluntariamente; ou 3) se adquiriu nova nacionalidade e goza da proteçáo do país cuja nacionalidade adquiriu; ou 4) se se estabeleceu de novo, voluntariamente, no país que abandonou ou fora do qual permaneceu por medo de ser perseguido; ou 5) se, por terem deixado de existir as circunstâncias em conseqüência das quais foi reconhecida como refugiada, ela não pode mais continuar a recusar valer-se da proteção do país de que é nacional."

4 "F. As disposiçôes desta Convenção não serão aplicáveis às pessoas a respeito das quais houver razóes sérias para pensar que: a) elas cometeram um crime contra a paz, um crime de guerra ou um crime contra a humanidade, no sentido dos instrumentos internacionais elaborados para prever tais crimes; b) elas cometeram um crime grave de direito comum fora do país de refúgio antes de serem nele admitidas como refugiados; c) elas se tornaram culpadas de atos contrários aos fins e princípios das Naçóes Unidas."

Vide: GEDIEL, J. A. Refúgio e hospitalidade. Curitiba: Kairós, 2016 e ANDRADE, J. H. F. de e MARCOLINI, A. A política brasileira de proteçáo e de reassentamento de refugiados: breves comentários sobre suas principais características. 2002, pp. 168-176. 
em seu artigo $1^{0^{6}}$ e inova quanto às hipóteses de exclusão:

Art. 3․ Não se beneficiarão da condição de refugiado os indivíduos que: I - já desfrutem de proteção ou assistência por parte de organismos ou instituição das Naçôes Unidas que não o Alto Comissariado das Naçóes Unidas para Refugiados - Acnur; II - sejam residentes no território nacional e tenham direitos e obrigaçóes relacionados com a condição de nacional brasileiro; III - tenham cometido crime contra a paz, crime de guerra, crime contra a humanidade, crime hediondo, participado de atos terroristas ou tráfico de drogas; IV sejam considerados culpados de atos contrários aos fins e princípios das Naçóes Unidas.

Veja-se que há previsão de hipótese de exclusão quanto ao cometimento de crimes hediondos, atos terroristas e tráfico de drogas, sem igual previsão específica na Convenção de 51 . Essa hipótese, no entanto, poderá afastar da aplicação da proteção de refugiados com fundamento apenas no que dispóe a legislação nacional a respeito do que sejam crimes hediondos. ${ }^{7}$

Da forma como inscrita, a cláusula de exceção na Lei 9.474, merece um estudo mais aprofundado, investigando-se sua pertinência para o afastamento da proteção do estatuto dos refugiados para indivíduos que se encontrem em situaçóes como a descrita.

O presente artigo pretende discutir e analisar a propriedade da cláusula de exclusão contida no art. $3^{\circ}$ da Lei $n^{\circ} 9.474$ e sua conformidade com a proteçáo internacional dos direitos humanos. Objetiva verificar em que medida o cometimento dos delitos apontados poderá descaracterizar a condição jurídica de refugiado e o perigo que essa exclusão pode representar ao indivíduo obrigado a retornar ao seu país de origem, bem como violação ao princípio do non-refoulement.

\footnotetext{
"Art. 10 Será reconhecido como refugiado todo indivíduo que: I - devido a fundados temores
de perseguição por motivos de raça, religião, nacionalidade, grupo social ou opinióes políticas encontre-se fora de seu país de nacionalidade e não possa ou não queira acolher-se à proteção de tal país; II - não tendo nacionalidade e estando fora do país onde antes teve sua residência habitual, não possa ou não queira regressar a ele em função das circunstâncias descritas no inciso anterior; III - devido à grave e generalizada violação de direitos humanos, é obrigado a deixar seu país de nacionalidade para buscar refúgio em outro país."

7 Em nossa atividade na Defensoria Pública, deparamo-nos com um caso envolvendo o cometimento de crime de tráfico de drogas por estrangeiro. Tratava-se de um colombiano preso em flagrante por estar supostamente vendendo substância entorpecente. $\mathrm{Na}$ audiência de instrução e julgamento, pode-se perceber que a maior preocupação do indivíduo era quanto ao seu retorno forçado à Colômbia (o que aconteceria em caso de condenaçáo, mediante o instituto da expulsão). Relatou-nos que veio ao Brasil em razão de temor por sua vida, por ter participado ativamente nas eleiçóes para prefeito de sua cidade (apoiando o candidato que acabou não se elegendo) com denúncias ao grupo das FARC e oposição. Estaria articulando a vinda de sua esposa, depois que a casa foi invadida e queimada. Estava instalado em Sáo Paulo, quando o transporte da droga lhe pareceu negócio rentável diante das dificuldades financeiras que suportava. Explicamos-lhe, então, a respeito do instituto do refúgio e a impossibilidade de aplicação em razão do crime que estava respondendo (do qual era réu confesso e acabou sendo condenado), embora merecesse a análise pelo órgão competente.
} 


\title{
1. DO ART. 3० DA LEI No 9.474-“(...) CRIME HEDIONDO, ATOS TERRORISTAS E TRÁFICO DE DROGAS”
}

Como mencionado, o artigo $3^{\circ}$ da Lei $n^{\circ} 9.474$ prevê as hipóteses de exclusão do reconhecimento da condição de refugiado. Dentre as hipóteses mencionadas, o inciso III merece maior atenção da doutrina, especialmente por ampliar o rol de exclusão da Convençâoo de 51 e encontrar referência inédita à Lei dos Crimes Hediondos e Equiparados.

A Convenção de 51 exclui da proteção jurídica as pessoas que cometem crimes graves fora do país de refúgio antes de serem admitidas como refugiados. Na esteira desse dispositivo, a Lei 9.474 exclui os indivíduos que praticaram os crimes de tráfico de drogas, crimes hediondos e atos terroristas. O desiderato da cláusula de exclusão, segundo aponta a doutrina é "o intuito de preservar o instituto, aplicando-o apenas aos que realmente são refugiados."

A ideia subjacente à afirmação posta se baseia no entendimento de que o autor dos atos de violência que gerariam o refúgio para tantas outras pessoas não pode, ele mesmo, pretender a proteção de direitos humanos, concernente ao direito de se refugiar. Nesse sentido, qualifica-o e classifica-o como "criminoso", que, no sentido teórico de Rousseau diz respeito ao inimigo social, rompendo a ideia de pacto social ${ }^{9}$. Michel Foucault, analisando as puniçóes surgidas a partir do regime penal, sintetiza o pensamento prevalente:

\begin{abstract}
Primeiramente, a punição expressa na afirmação - 'você rompeu o pacto social, você não pertence mais ao corpo social, você mesmo se colocou fora do espaço de legalidade; nós o expulsaremos do espaço social onde essa legalidade funciona'. É a idéia encontrada frequentemente nesses autores - Beccaria, Bentham, etc. - de que, no fundo, a punição ideal seria simplesmente expulsar as pessoas, exilálas, bani-las, ou deportá-la. ${ }^{10}$
\end{abstract}

Ou seja, afastá-las da concessão de direitos.

A previsão da cláusula de exclusão na Convenção de 51 no que tange à exclusão daqueles que cometeram crime contra a paz, de guerra, contra a humanidade, ou um crime grave de direito comum é explicada pelo próprio Alto Comissariado das Naçóes Unidas (Acnur) por uma razão histórica:

\footnotetext{
8 JUBILUT, L. L. O Direito Internacional dos Refugiados e sua Aplicaçáo no Ordenamento Jurídico Brasileiro, 2007, p. 87.

9 Vide: ROUSSEAU, J. J. (Trad. Rolando Roque da Silva). Do contrato social. VirtualBooks. Formato: e-book/rb, ed. eletrônica: Ridendo Castigat Mores, 2002.

10 FOUCAULT, M. A verdade e as formas jurídicas, 2005, p. 82.
} 
Na altura em que a Convenção foi redigida, a memória dos julgamentos dos grandes criminosos de guerra não estava ainda muito presente e os Estados acordaram em que os criminosos de guerra não deveriam ser protegidos. Houve também a vontade, por parte dos Estados, de negar a admissão nos seus territórios a criminosos que constituíssem perigo para a segurança e ordem pública. ${ }^{11}$

A dificuldade inicialmente apresentada diz respeito ao "conhecimento da verdade" 12 . Como apurar se o requerente do refúgio é autor de atos de violência? É preciso processo/ condenação ${ }^{\text {13 }}$ Neste caso, vale a condenação do país de origem (que está sendo palco de atos de violência generalizada) ou deve-se apurar no país em que o pedido de refúgio está sendo requerido? Seriam suficientes meras elucidaçóes da participação do autor? Poderia o requerente do refúgio "se defender" de que praticou os atos por alguma causa excludente (legítima defesa, estrito cumprimento do dever legal, estado de necessidade, cumprimento de ordem superior hierárquica não manifestamente ilegal)?

O próprio Acnur reconhece o caráter vago que pode ser dado à interpretação da cláusula de exclusão quanto ao cometimento de crimes comuns graves da forma expressa na Convenção de $51^{14}$. Primeiramente, diante da possibilidade de os Estados partes da Convenção de 51 definirem o que seriam "crimes graves", havendo distinçóes significativas dependendo do país signatário da Convenção.

Outra questão importante de ser discutida reveste-se no fato, não mencionado expressamente na cláusula de exclusão da Lei no 9.474 , de "se" o crime praticado pelo requerente do refúgio deve ter alguma relação com os atos de violência ocorridos no seu país, ou seja: as consideraçóes espaço-temporais do suposto crime praticado. $\mathrm{O}$

$11 \quad$ ACNUR Brasil. Manual de Procedimentos e Critérios para Determinar a Condição de Refugiado de acordo com a Convençáo de 1951 e o Protocolo de 1967 relativos ao Estatuto dos Refugiados, 2004, p. 51.

12 Sobre "a verdade", afirma FOUCAULT: "A hipótese que gostaria de propor é que, no fundo, há duas histórias de verdade. A primeira é uma espécie de história interna da verdade, a história de uma verdade que se corrige a partir de seus próprios princípios de regulaçáo: é a história da verdade tal como se faz na ou a partir da história das ciências. Por outro lado, parece-me que existem, na sociedade, ou pelo menos em nossas sociedades, vários outros lugares onde a verdade se forma, onde um certo número de regra de jogo sáo definidas - regras de jogo a partir das quais vemos nascer certas formas de subjetividade, certos domínios de objeto, certos tipos de saber - e por conseguinte podemos, a partir daí, fazer uma história externa, exterior, da verdade." FOUCAULT, M. A verdade e as formas jurídicas. Rio de Janeiro: NAU Editora, 2005, p.11.

13 Segundo o Manual do Acnur, "é suficiente demonstrar que existem 'razóes poderosas para pensar' que foi cometido um dos atos descritos. A prova formal de anterior procedimento judicial náo é requerida". ACNUR Brasil. Manual de Procedimentos e Critérios para Determinar a Condição de Refugiado de acordo com a Convençáo de 1951 e o Protocolo de 1967 relativos ao Estatuto dos Refugiados, 2004, p.51.

$14 \quad \mathrm{Na}$ Convenção de 51 , não há referência aos crimes hediondos, mas aos crimes graves, expressão ainda mais vaga. ACNUR Brasil. Manual de Procedimentos e Critérios para Determinar a Condição de Refugiado de acordo com a Convenção de 1951 e o Protocolo de 1967 relativos ao Estatuto dos Refugiados, 2004, p.60. 
cometimento de crime hediondo posteriormente ao ingresso do estrangeiro no país, mas anteriormente ao seu pedido de refúgio, impede a análise pelo órgão competente?

Essa indagação se coloca diante do art. 26 da Lei no 9.474 que considera a decisão pelo reconhecimen to da condição de refugiado ato declaratório - ou seja, reconhece uma situação jurídica já existente no momento de ingresso do estrangeiro no território nacional. ${ }^{15}$ Pela leitura do dispositivo, náo seria o caso de denegar o reconhecimento do status de refugiado em caso de cometimento de crime hediondo posterior, mas eventualmente determinar a sua perda com base no art. 39 da mesma legislação (Art. 39). Implicará perda da condição de refugiado: [...] III - o exercício de atividades contrárias à segurança nacional ou à ordem pública). Esse entendimento, inclusive, pode ser corroborado pelo artigo $1^{\circ} \mathrm{da}$ própria Convenção de 51 que assenta, quanto à cláusula de exclusão de que o crime grave praticado deve ser anterior e fora do país em que o pedido de refúgio está sendo requerido (art. $1^{\circ}[\ldots], \mathrm{b}$ - elas cometeram um crime grave de direito comum fora do país de refúgio antes de serem nele admitidas como refugiados).

Por fim, outro ponto importante revela-se quanto à proporcionalidade do cometimento de crime hediondo e afins (tráfico de drogas e atos de terrorismo) com a sanção da impossibilidade do reconhecimento da condição de refugiado. $\mathrm{O}$ artigo $1^{\circ} \mathrm{da}$ Lei no 8.072 define como hediondos os crimes de:

I - homicídio, quando praticado em atividade típica de grupo de extermínio, ainda que cometido por um só agente, e homicídio qualificado II - latrocínio, III - extorsão qualificada pela morte, IV extorsão mediante seqüestro e na forma qualificada, V - estupro, VI - atentado violento ao pudor, VII - epidemia com resultado morte, VII-B - falsificação, corrupçáo, adulteração ou alteração de produto destinado a fins terapêuticos ou medicinais. VIII - favorecimento da prostituiçáo ou de outra forma de exploração sexual de criança ou adolescente ou de vulnerável (art. 218-B, caput, e $\$ \$ 1^{\circ}$ e $2^{\circ}$ ). Parágrafo único. Consideram-se também hediondos o crime de genocídio previsto nos arts. 1o, 2o e 3o da Lei no 2.889 , de 1 o de outubro de 1956, e o de posse ou porte ilegal de arma de fogo de uso restrito, previsto no art. 16 da Lei no 10.826 , de 22 de dezembro de 2003, todos tentados ou consumados.

Importante consignar que a referência a crime hediondo somente apareceu em 1988 na Constituição da República, justamente no capítulo referente aos direitos fundamentais (art. 5, XLIII). Analisando os fundamentos históricos da qualificação desses crimes, Alberto Silva Franco justifica em função do aumento do ponto de vista estatístico, do

15 Vide: JUBILUT, L. L., O procedimento de Concessáo de Refúgio no Brasil. Disponível em: <www.mj.gov.br/services/.../FileDownload.EZTSvc.asp?>. 
dano econômico, atingindo seguimentos sociais que até então estavam livres de ataques criminosos. A partir desse quadro, os meios de comunicação de massa começaram a atuar por interesses políticos subalternos, de forma a exagerar a situação real, formando uma idéia de que seria mister, para desenvolvê-la, uma luta sem quartel contra determinada forma de criminalidade ou determinados tipos de delinqüentes, mesmo que tal luta viesse a significar a perda das tradicionais garantias do próprio Direito Penal e do Direito Processual Penal ${ }^{16}$.

A análise histórica da classificação de novos crimes como hediondos demonstra a atuação desse papel de pressáo social e de influência da mídia ${ }^{17}$, o que pode ser observado tanto na inclusão pela Lei no 8.930 do homicídio qualificado após um célebre caso de homicídio envolvendo uma atriz famosa no âmbito televisivo, quanto na alteração pela Lei no 9.695, incluindo a falsificação de remédios, após ser noticiada a existência de uma quadrilha atuando ilegalmente na saúde pública. $\mathrm{O}$ rol desses crimes hediondos sofre, de um lado essas pressôes por sua ampliação, de outro, críticas por inserir crimes "menos graves" na mesma categoria ${ }^{18}$.

O tratamento mais severo dos crimes hediondos, tráfico de drogas e equiparados pelo legislador, como a proibiçáo de liberdade provisória e cumprimento da pena integralmente em regime fechado, já foram objeto de críticas pela doutrina e jurisprudência e alterados pela Lei 11.464/2007. Entre o desejo de punir severamente do Estado de um lado e os direitos fundamentais do apenado de outro (individualização da pena, princípios da humanidade, proibição de penas perpétuas), decidiu-se que estes deveriam prevalecer, embora nem sempre a balança tenda para esse lado. ${ }^{19}$

Se essa ponderação pode se colocar frente aos direitos fundamentais do apenado, não sem menor razão, essa mesma proporcionalidade deve ser aferida em relação aos direitos do refugiado diante de uma cláusula de exclusão e a necessidade de proteger às pessoas que são obrigadas a deixar o seu país de origem. ${ }^{20}$

$\mathrm{O}$ art. $4^{\circ}$ da Constituição estabelece os princípios adotados pelo país em suas relaçóes internacionais, inserindo, expressamente a cooperação entre os povos para o progresso da humanidade e a concessão de asilo político. $\mathrm{O}$ instituto do asilo não se confunde

\footnotetext{
16 TOURINHO FILHO, F. da C. Processo Penal, 2014, p. 456.

17 Vide: BARATTA, A. Criminologia crítica e crítica ao direito penal: introdução à sociologia do direito penal. Trad. Juarez Cirino dos Santos. 2002, p. 162 e ss. Ainda, ROXIN, C. Política criminal e sistema jurídico penal, 2000. e GOMES, L. F. Mídia e Direito Penal. Revista Jus Navigandi, 2009. Disponível em: <https://jus.com.br/artigos/12274>.

18 Por exemplo, quanto ao crime de estupro de vulnerável com violência presumida a jurisprudência é vacilante em considerar como crime hediondo. Vide GOMES, L. F. "Estupro e atentado violento ao pudor simples são crimes hediondos?” In: www.ibccrim.com.br.

19 Vide: STF, ARE 663261 e HC 97256 sobre a possibilidade de substituição de pena privativa de liberdade por restritivas de direitos no tráfico de drogas. www.stf.jus.br. Vide ainda MORAES, A. R. A. de. A terceira velocidade do direito penal: o "direito penal do inimigo". 2006. Dissertação (Mestrado).

20 Vide: TRINDADE, A. A. C. Reflexiones sobre el desarraigo como problema de Derechos Humanos frente a la conciencia Jurídica Universa. In: TRINDADE, A. A. C.; SANTIAGO, J. R. de. La nueva dimension de las necessidades de protección del ser bumano en el início del siglo XXI. 2002, p. 21-81.
} 
com o refúgio ${ }^{21}$, embora ambos apresentem a característica de permitir, ao estrangeiro, a proteção do Estado acolhedor ${ }^{22}$. A doutrina salienta que, apesar de a Constituição utilizara expressão asilo político, entende-se que ela está se referindo ao direito de asilo em sua totalidade. ${ }^{23}$

Além disso, a referência aos direitos fundamentais no art. $5^{\circ}$ caput da Carta Magna é expressa no sentido de garantir aos brasileiros e estrangeiros ${ }^{24}$, a inviolabilidade do direito à vida, à liberdade, à igualdade, à segurança e à propriedade. Nesse sentido, mesmo a análise do pedido de refúgio deve estar alinhada aos princípios e garantias fundamentais. Quando a sua denegação implicar possível violação de direito fundamental (ex: risco à vida), o valor protegido deve ser confrontado com as razóes motivadoras do indeferimento.

Importante consignar que a Lei 9.474 foi resultado do Programa Nacional de Direitos Humanos de 1996 e elaborada em conjunto com representantes do Acnur. A análise da Lei revela a adoção do "espírito de Cartagena" ${ }^{25}$, para ampliar a definição de refugiado, ${ }^{26}$ abarcando as pessoas que fogem de graves e generalizadas violaçóes de direitos humanos. Busca-se, por este lado, conferir maior proteção às vítimas. Por outro lado, a lei brasileira também ampliou o âmbito de incidência da cláusula de exclusão, fazendo referência ao cometimento de crimes hediondos, tráfico de drogas e atos de terrorismo, reforçando a categorização "vítima x violador".

Neste ponto, o legislador abraçou os mesmos argumentos utilizados para o tratamento mais severo dos acusados de certos crimes no sentido de limitar o reconhecimento do status de refugiado e a concessão de direitos que esse status impóe. Enquanto parte da doutrina entende que essa ampliação pode ser vista como uma adaptação e atualização do texto aos novos problemas do cenário internacional, ${ }^{27}$ entendemos que essa ampliação viola o espírito do próprio direito dos refugiados, ampliando as formas de exclusão da Convenção de 51 (considerando que o Brasil não fez reservas a essa Convenção) e

21 Disponível em: www.mj.gov.br.
22 A identidade entre ambos e ressaltada pela própria Declaração Universal de Direitos Humanos de 1948.
Não inserida especificamente nas questóes políticas da América, define como direito humano: "art. 14. A todo ser
humano vítima de perseguiçáo, o direito de procurar e gozar asilo em outros países, com o que a pessoa sujeita a castigo
por razóes de ordem política, religiosa ou racial ou por sua luta contra o colonialismo pode socorrer-se do instituto."
$23 \quad$ JUBILUT, L. L. O Direito Internacional dos Refugiados e sua Aplicaçáo no Ordenamento Jurídico Brasileiro. São Paulo: Método, 2007, p. 181. BATISTA, V. de O. União Européia: Livre circulação de pessoas e Direito de Asilo. Belo Horizonte: Del Rey, 1997, p. 52. 24 A indicação quanto aos "estrangeiros residentes no País". Vide: RAMOS, A. de C. Curso de Direitos Humanos. São Paulo: Saraiva, 2016.

25 Referência à Declaração de Cartagena de 1984.

26 Vide:ALMEIDA, G. A. de. A Lei $9.474 / 97$ e a definição ampliada de refugiado: breves consideraçóes. In: ARAÚJO, N. de; ALMEIDA, G. A. de. (coords.) O Direito Internacional dos Refugiados: uma perspectiva brasileira. 2001. p.155 e segts.

$27 \quad$ JUBILUT, L. L. O Direito Internacional dos Refugiados e sua Aplicaçáo no Ordenamento Jurídico Brasileiro, 2007, p. 191. A autora ressalta as duas hipóteses: "tal ampliação pode ser vista como uma limitação indevida da Convenção de 51, uma vez que o Brasil não adotou reservas sobre o tema quando da ratificação desse documento, mas pode ser vista como uma adaptação e atualização do texto aos novos problemas do cenário internacional, problemas que caracterizam atos contrários aos princípios da ONU e poderiam ser entendidos como já englobados na Convenção de 51.” 
constituindo violação a direitos humanos fundamentais.

Se é a própria lei quem define os chamados crimes hediondos, da forma como foi analisada anteriormente, teríamos, em última análise, a sujeição da disciplina dos Direitos dos Refugiados às intempéries do legislador infraconstitucional. Essa sujeição viola o compromisso internacional do país em tutelar o Direito dos Refugiados na forma da Convenção de 51, passível, portanto, de responsabilização internacional. Além disso, desvirtua a própria hierarquia constitucional quanto aos princípios e direitos fundamentais, constituindo limitaçóes e violaçóes indevidas a direitos e garantias constitucionalmente asseguradas.

Assim é que a maneira como está disposta a cláusula de exclusão - na legislação infraconstitucional pela Lei no 9.474 , integrada por outras legislaçóes infraconstitucionais que definem os crimes hediondos e afins - viola a Constituição Federal, no que tange aos princípios das relaçóes internacionais e respeito aos direitos e garantias fundamentais, e, ainda, ao compromisso internacional assumido pelo país em defender o direito dos refugiados.

\section{O DIREITO DOS REFUGIADOS COMO PARTE DOS DIREITOS HUMANOS}

Conforme enfatiza Resek, "nenhum Estado soberano é obrigado, por princípio de direito das gentes, a admitir estrangeiros em seu território, seja em definitivo, seja a título temporário." ${ }^{28}$ Trata-se, segundo o autor, de poder discricionário do Estado, como exercício de sua soberania, admitir ou não pessoas que não sejam de sua nacionalidade. ${ }^{29}$

Esse entendimento expressa um conceito clássico de soberania, que vem, ao longo dos anos, sendo "relativizado e suavizado." ${ }^{30} \mathrm{O}$ exercício da soberania está relativamente limitado pelas normas de Direito Internacional, sendo necessário o respeito a todas as obrigaçôes básicas reconhecidas pelo Direito Internacional. Dentre essas obrigaçóes está a obediência, pelo Estado, aos Direitos Humanos e aos tratados de que é parte.

Os Direitos Humanos têm sua gênese como Direito Internacional a partir da Declaração Universal dos Direitos Humanos (DUDH) de 1948 e dos instrumentos de proteção que se seguiram. Conforme Flávia Piovesan, o processo de universalização dos direitos humanos permitiu a formação de um sistema internacional de proteção desses direitos. ${ }^{31}$ Tal sistema, acrescenta a autora:

é integrado por tratados internacionais de proteção e refletem,

\footnotetext{
$28 \quad$ RESEK, F. Direito Internacional Público, 2008, p. 193.

29 Cada Estado adota seus próprios critérios para definir a nacionalidade.

30 JO, H. M. Introduçáo ao Direito Internacional, 2004, p. 364.

31 PIOVESAN, F. Direitos Humanos e Justiça Internacional, 2006, p. 13.
} 
sobretudo, a consciência ética contemporânea compartilhada pelos Estados, na medida em que invocam o consenso internacional acerca de temas centrais aos direitos humanos, na busca de salvaguarda de parâmetros protetivos mínimos - 'do mínimo ético irredutível.'

A soberania passa a ser confrontada com o respeito aos Direitos Humanos e esses passam para o ponto nodal de todo o sistema internacional. Se, no exercício de sua soberania, os Estados aceitam as obrigaçóes jurídicas decorrentes dos tratados de direitos humanos, passam, entáo, a se submeter à autoridade das instituiçóes internacionais, no que se refere à tutela e fiscalização desses direitos em seu território. ${ }^{32} \mathrm{~A}$ mesma relação interna de interdependência que se estabelece entre os direitos fundamentais e todo o ordenamento jurídico (esses dotados de superioridade valorativa) passa, no plano do Direito Internacional, no que diz respeito à proteção dos direitos humanos e todas as demais obrigaçóes e relaçóes internacionais, especialmente em relação ao deslocamento forçado de pessoas. ${ }^{33}$ Considerando que os Estados devem obedecer aos Direitos Humanos e a sua superioridade valorativa na seara internacional, a investigação que se apresenta em relação ao refúgio está centrada em sua natureza jurídica. Constitui ato de tolerância do Estado com o estrangeiro ou direito humano?

Afirma o artigo 14 da DUDH: "toda pessoa vítima de perseguição tem o direito de procurar gozar asilo em outros países". Acrescenta o mesmo dispositivo " 2 - este direito não pode ser invocado em caso de perseguição legitimamente motivada por crimes de direito comum ou por atos contrários aos propósitos e princípios das Nações Unidas”.

A proteção dos refugiados e seu reconhecimento jurídico ocorreram três anos após com a Convenção de 51. ${ }^{34}$ Antônio Augusto Cançado Trindade ressalta a sua natureza jurídica como "uma vertente da proteçáo internacional dos direitos da pessoa humana,"35 juntamente com os Direitos Humanos strictu sensu e o Direito Humanitário. Enfatiza o autor: "considerar as três vertentes em seu conjunto (tomando os direitos humanos lato sensu), é um imperativo de nossos dias, ainda mais por desvendarem elas, crescentes aproximaçóes e convergências, nos planos normativos, hermenêutico e operacional.”

Essa interdependência dos Direitos Humanos e os Direitos dos Refugiados é enfatizada pela doutrina. ${ }^{36}$ Nesse sentido, assinala Flávia Piovesan:

32 PIOVESAN, F. Direitos Humanos e Direito Constitucional Internacional. Saraiva: São Paulo, 2007, p. 9. A autora destaca a afirmação do Secretário-Geral da ONU em 1992, nesse ponto: "ainda que o respeito à soberania e integridade do Estado seja uma questáo central, é inegável que a antiga doutrina da soberania exclusiva e absoluta não mais se aplica e que esta soberania jamais foi absoluta, como era então concebida teoricamente. Uma das maiores exigências intelectuais de nosso tempo é a de repensar a questão a soberania $[\ldots]$.”

33 Vide: PITA, A. C. Direitos Humanos e Asilo. In: MILESE, R. (org.) Refugiados: Realidade e Perspectivas. São Paulo: Loyola/IMDG/CSEM, 2003. p. 87

34 Vide: JAEGER, G. On the History of the International Protection of Refugees. International Review of the Red Cross, Setembro 2001. Disponível em: https://www.icrc.org/ara/assets/files/other/727_738_ jaeger.pdf.

35 TRINDADADE, A. A. C. A Proteçáo Internacional dos Direitos Humanos e o Brasil, 2000 , p. 72. 36 Vide: TRINDADADE, A. A. C. A Proteçáo Internacional dos Direitos Humanos e o Brasil, 2000 . 
quando se relaciona refugiados e direitos humanos, imediatamente percebe-se uma conexão fundamental: os refugiados tornam-se refugiados porque um ou mais direitos fundamentais são ameaçados. Cada refugiado é conseqüência de um Estado que viola os direitos humanos. ${ }^{37}$

E conclui:

Há, assim, uma relação estreita entre a Convenção de 1951 e a Declaração Universal de 1948, em especial seu artigo 14, sendo hoje impossível conceber o Direito Internacional dos Refugiados de maneira independente e desvinculado do Direito Internacional dos Direitos Humanos. ${ }^{38}$

Nesse sentido, podemos concluir com Liliana Lyra Jubilut:

verifica-se que o Direito Internacional dos Refugiados é uma vertente do
Direito Internacional dos Direitos Humanos, sendo esta a sua natureza
jurídica, o que implica aspectos positivos e aspectos negativos; o principal
aspecto positivo é o fato de ser ele parte de um elenco de direitos universais,
indivisíveis interdependentes e inter-relacionados e essenciais ao ser humano,
e o principal aspecto negativo é a questáo da sua efetividade. ${ }^{39}$

A efetividade dos Direitos dos Refugiados ainda depende da atuação positiva dos Estados, tanto por meio de instrumentos legislativos de reconhecimento dessa condição jurídica (ratificação da Convençấo e ediçẫo de leis internas específicas) quanto por meio de implementação de condiçóes materiais de assentamento (condiçóes de trabalho, moradia, saúde, etc.).

Quanto ao reconhecimento dessa condição jurídica, o Brasil estabeleceu essa função ao Conare (Comitê Nacional para Refugiados), órgão colegiado vinculado ao Ministério da Justiça. ${ }^{40}$ Compete ao Conare, dentre outras atribuiçóes, "analisar o pedido sobre o reconhecimento da condição de refugiado (com possibilidade de recurso ao Ministro da Justiça), deliberar quanto à cessação 'ex officio' ou mediante requerimento das autoridades

37 PIOVESAN, F. O direito de asilo e a proteção internacional dos refugiados. In: ARAÚJO, N. de; ALMEIDA, G. A. (coords.) O Direito Internacional dos Refugiados: uma perspectiva brasileira. Rio de Janeiro: Renovar, 2001. p. 38.

38 PIOVESAN, F. O direito de asilo e a proteção internacional dos refugiados. In: ARAÚJO, N. de; ALMEIDA, G. A. (coords.) O Direito Internacional dos Refugiados: uma perspectiva brasileira. Rio de Janeiro: Renovar, 2001. p. 38-39.

39 JUBILUT, L. L. O Direito Internacional dos Refugiados e sua Aplicaçáo no Ordenamento Jurídico Brasileiro, 2007, p. 64.

40 Vide: LEÃO, R. Z. R. A temática do Refúgio no Brasil após a Criação do CONARE. In: MILESI, Rosita. (org.) Refugiados: Realidade e Perspectivas. São Paulo: Loyola/IMDG/CSEM, 2003. p. 173-96. 
competentes da condição de refugiado e declarar a perda da condição de refugiado" ${ }^{41}$.

Se, por um lado, representa maior disposição governamental em tratar do tema dos refugiados, por outro, pode significar discricionariedade e excesso de soberania, no que se refere à necessidade de reconhecimento formal pelo próprio Estado para a existência do direito ao refúgio. Essa discricionariedade não é aceita pela doutrina, com base ainda no compromisso internacional de proteção do refúgio. Segundo Del'Omo, enquanto que “o asilo depende do Estado, sendo lícita a negativa do mesmo, o refúgio, por estar acordado em Convenção, não pode ser recusado pelo país signatário.” ${ }^{42}$

Assim o reconhecimento do status de refugiado deve ter em conta, além da natureza jurídica do Direito dos Refugiados como parte dos Direitos Humanos, o compromisso internacional do Brasil em protegê-los. ${ }^{43}$ Logo, qualquer discussão a respeito do reconhecimento da condição de refugiado pode ser levada ao Poder Judiciário, mesmo que não haja previsão expressa na Lei no 9.474. Trata-se de garantia fundamental consubstanciada no art. $5^{\circ}$, inciso XXXV, da Constituição Federal ${ }^{44}$ e da incumbência ao Judiciário $^{45}$ de garantir, em última análise, o respeito à ordem constitucional. ${ }^{46}$

O Direito dos Refugiados, assim, passa a ser considerado tanto parte dos Direitos Humanos, inserido em instrumento formal de reconhecimento (Convenção de 51 e legislaçóes internas), como também, quanto a alguns aspectos, parte do jus cogens e costume internacional, tamanha a importância que representa na comunidade internacional. Nesse ínterim, a doutrina defende o princípio do non-refoulement, no que tange à impossibilidade de o refugiado ser devolvido ao país no qual foi vítima de perseguiçóes e violações de direitos humanos como parte do jus cogens. ${ }^{47}$

O princípio do non-refoulement está consubstanciado no art. 33 da Convenção de 51 :

Art. 12 da Lei no 9.474 .

42 DEL'OMO, F. de S. Curso de Direito Internacional Público. 2006, p. 217. Vide ainda BARRETO,

L. P. F. T. Das diferenças entre os institutos jurídicos do asilo e do refúgio. Disponível em: <www.migrante. org.br/Asilo\%20e\%20Refugio\%20diferencas.doc>.

43 Vide HAYDU, M. O envolvimento do Brasil com a problemática dos refugiados: um breve histórico. Revista Ponto-e-Vírgula, p. 183-200, 2009/2.

$44 \quad$ Art. 5\%, XXXV - a lei não excluirá da apreciação do Poder Judiciário lesão ou ameaça a direito.

45 Vide MORAES, T. G. A. de. O papel do Judiciário na proteçáo dos refugiados. Revista da Faculdade de Direito: Universidade Federal do Rio Grande do Sul. 2014, p. 164-181.

46 Exemplo do conhecido caso Battisti. Vide, entre outros, CAPUTO BASTOS, C. E. e GARCIA, M. Judiciário pode rever decisão que deu refúgio a Battisti. Revista Consultor Jurídico. Conjur, 10/03/2009. Disponível em <http://www.conjur.com.br/2009-mar-10/judiciario-rever-decisao-ministerial-deu-refugiobattisti>.

47 PIOVESAN, F. O direito de asilo e a proteção internacional dos refugiados. In: ARAÚJO, N. de; ALMEIDA, G. A. (coords.) O Direito Internacional dos Refugiados: uma perspectiva brasileira. Rio de Janeiro: Renovar, 2001. p. 47. LUZ FILHO, J. F. S. Non-refoulement: breves consideraçóes sobre o limite jurídico à saída compulsória do refugiado. In: ARAÚJO, N. de; ALMEIDA, G. A. de. (coords.) O Direito Internacional dos Refugiados: uma perspectiva brasileira. 2001. p. 207. ALLAIN, J. The jus cogens nature of non-refoulement. Int J Refugee Law 2001, p. 534. 
Nenhum dos Estados contratantes expulsará ou rechaçará, de maneira alguma, um refugiado para as fronteiras dos territórios em que a sua vida ou a sua liberdade seja ameaçada em virtude de sua raça, da sua religiáo, da sua nacionalidade, do grupo social a que pertence ou das suas opinióes políticas.

Na Lei no 9.474 esse princípio se concretiza na impossibilidade de deportação, extradição e expulsão do refugiado. Quanto à expulsão, existe, tanto na Convenção de 51 (art. 32), quanto na legislação nacional, a impossibilidade desse instituto ao regularmente registrado. Registre-se que apenas recentemente o instituto da expulsão ganhou nova roupagem com a Lei de Migração - Lei 13.445/2017, havendo, na lei anterior, referência à segurança e ordem nacional, o que poderia configurar grave violação de direitos humanos.

Assim, é necessário conciliar o princípio do non-refoulement, reconhecido inclusive como parte do jus cogens, às hipóteses tratadas pela legislação nacional de saída compulsória do estrangeiro, chegando-se à única conclusão de que não pode ter aplicação o art. 36 da Lei no 9.474, por violação aos Direitos Humanos, à Constituição e aos compromissos internacionais assumidos pelo país. ${ }^{48} \mathrm{O}$ referido dispositivo, inclusive, deve ter tido como revogado pela nova Lei de Migração que deu novo conteúdo ao instituto da expulsão.

Por fim, a Lei no 9.474 apresenta ainda uma última restrição ao Direito dos Refugiados. Trata-se da perda em razão do exercício de atividades contrárias à segurança nacional ou à ordem pública, sujeitando os infratores às medidas compulsórias previstas na Lei no 6.815 (art. 39, III e parágrafo único), revogada pela novel legislação migratória. Veja-se que não há a mesma restriçãao por parte da Convenção de 51 e tal consideração poderá implicar restrição indevida ao direito humano de refúgio, até porque deixa a critério do Conare a decisão quanto a essa perda da condição de refugiado. Assim, como não há mais referência na Lei de Migração à segurança nacional, também em relação ao refúgio essa limitação não pode prevalecer.

Todas essas restrições identificadas ao direito de refúgio não se coadunam com a natureza jurídica estabelecida de Direito Humano, revelando, portanto que a saída do estrangeiro não pode se dar sem uma consideração mais ampla sobre o instituto do refúgio. ${ }^{49}$ Qualquer restrição a um direito humano deve obrigatoriamente passar por um juízo de ponderação. ${ }^{50}$ Deve-se aferir, segundo o princípio da proporcionalidade, se essa restrição é legítima. No que tange ao instituto do refúgio, qualquer restrição deve ter em conta sua natureza como parte dos direitos humanos e, portanto, não poderá ser pautada apenas por critérios de conveniência e discricionariedade da Administração.

\footnotetext{
48 Vide LAUTERPACHT, S. E.; BETHLEHEM, D. The scope and content of the principle of non-refoulement: Opinion. In: UN High Commissioner for Refugees (UNHCR). Global Consultations on International Protection/Second Track], 20 June 2001. Disponível em:<http://www.refworld.org/ $\mathrm{docid} / 3 \mathrm{~b} 3702 \mathrm{~b} 15 . \mathrm{html}>$.

49 Vide LUIZ FILHO, J. F. S. Non-refoulement: breves considerações sobre o limite jurídico à saída compulsória do refugiado. In: ARAÚJO, N. de; ALMEIDA, G. A. de (Org.). O Direito internacional dos refugiados: uma perspectiva brasileira, 2001, p. 182-183.
} 
As restriçóes, como a cláusula de exclusão e as hipóteses de perda, devem ser mensuradas segundo esse juízo valorativo que é próprio dos princípios constitucionais fundamentais e também da proteção efetiva dos Direitos Humanos, revelando verdadeiro controle de convencionalidade. ${ }^{51}$ Deve-se ser aferido, caso a caso, os limites de diminuição do direito ao refúgio frente a outros valores também defendidos pelo Estado soberano.

\section{CONSIDERAÇÓES FINAIS}

A cláusula de exclusão, especialmente da forma como exposta na Lei no 9.474 no que tange ao cometimento de crimes graves, hediondos, atos de terrorismos e tráfico de drogas não pode retirar a condiçáo de refugiado estabelecida pelos Direitos Humanos. Parte-se da consideraçáo dessa natureza jurídica ao instituto do refúgio.

Em um primeiro momento, porque a Lei no 9.474 ampliou as hipóteses da cláusula de exclusão estabelecidas na Convenção de 51 . Essa ampliação feita pelo legislador ordinário implica diretamente restriçãao desproporcional aos direitos humanos e à Constituição. $\mathrm{O}$ próprio rol dos crimes hediondos, como se verificou, sofre influências e pressóes sociais que desestabilizam a segurança necessária que deve pautar a proteção ao refugiado. Além disso, o tráfico de drogas possui estrita ligação com a camada mais pobre da população: quer por ausência de alternativas econômicas (aliciamento das chamadas mulas, fogueteiros, etc.) quer por inserirem-se, como organização criminosa, dentro dos bairros e favelas pobres das cidades brasileiras ${ }^{52}$.

As discussóes a respeito desses crimes merecem uma análise social do problema da criminalidade e não podem ser concebidas a partir de uma restrição, cada vez maior, a direitos fundamentais. $\mathrm{O}$ reconhecimento do refúgio não pode estar atrelado à repressão ao cometimento de crimes graves na sociedade. Por exemplo, aumentando o rol dos crimes hediondos, por decisóes de políticas repressivas de combate à criminalidade, teríamos o efeito de menos reconhecimento de indivíduos com status de refugiados, o que não se equilibra com o próprio fundamento do instituto do refúgio, que busca, a partir da Declaração de Cartagena, ampliar as hipóteses de reconhecimento.

Além disso, o cometimento desses crimes da forma como estabelecida na Lei no 9.474 não esclarece a necessidade de pertinência com os atos de violência que ensejaram o refúgio e consideraçóes espaço-temporais do fato. Por exemplo, o fato do indivíduo posteriormente ao ingresso no Brasil cometer tráfico de drogas deve impedir o reconhecimento do refúgio? Se atentarmos a natureza declaratória do instituto, não pode haver esse impedimento.

\footnotetext{
51 Vide, por todos, MAZZUOLI, V.; MARINONI, L. G. Controle de Convencionalidade, 2013.

52 Relatório da Anistia Internacional revela a violação de direitos humanos nas comunidades socialmente excluídas do Brasil a pretexto do combate ao tráfico de drogas. Segundo informa, o tráfico de drogas se instalou nessas comunidades pobres, preenchendo um vazio deixado pelo Estado, com poucos ou até nenhum serviço público. Fonte: www.dhnet.org.br.
} 
Não se trata de defender a ausência de punição ao indivíduo beneficiado com o refúgio que venha a cometer um crime no Estado concedente. A punição, entretanto, não poderá ser a retirada de Direito Humano reconhecida por sua condição de refugiado. Cumprirá as mesmas medidas para os nacionais do país concedente: penas privativas de liberdade, restritivas de direitos, etc.

Por fim, concebendo o Direito dos Refugiados como Direito Humano universal este não poderá sofrer limitaçóes legislativas que impliquem restrição e violações à proteção à pessoa. Essas restriçóes apenas se justificariam na premissa equivocada de que o reconhecimento do refúgio é ato de soberania e discricionário do Estado-nacional ${ }^{53}$.

Admitindo-se a natureza de Direitos Humanos ao Direito dos Refugiados, a sua proteção não pode estar condicionada à atuação positiva do indivíduo na sociedade, pois o respeito aos direitos humanos tem aplicação universal e incondicional. Tampouco poderá depender de decisóes político-administrativas do Estado concedente do refúgio, ou consideraçóes da perda como na possibilidade de expulsar a pessoa protegida pelo direito do refúgio.

\section{REFERÊNCIAS}

ACNUR Brasil. Manual de Procedimentos e Critérios para Determinar a Condiçáo de Refugiado de acordo com a Convençáo de 1951 e o Protocolo de 1967 relativos ao Estatuto dos Refugiados, 2004.

AGUIAR, R. Lei 9.474/97: cláusulas de inclusão e exclusão. In: ARAÚJO, Nadia de; ALMEIDA, G. A. de. (coords.) O Direito Internacional dos Refugiados: uma perspectiva brasileira. Rio de Janeiro: Renovar, 2001. p.211-32.

ALLAIN, J. The jus cogens nature of non-refoulement. Int J Refugee Law (2001) 13 (4): 533-558. Oxford University Press, 2001.

ALMEIDA, G. A. de. A Lei 9.474/97 e a definição ampliada de refugiado: breves consideraçōes. In: ARAÚJO, N. de; ALMEIDA, G. A. de. (coords.) O Direito Internacional dos Refugiados: uma perspectiva brasileira. Rio de Janeiro: Renovar, 2001. p.155- 67.

ANDRADE, J. H. F. de e MARCOLINI, A. A política brasileira de proteção e de reassentamento de refugiados: breves comentários sobre suas principais características. Rev. bras. polit. int. 2002, vol.45, n.1, pp. 168-176. Disponível em:<http://www.scielo. $\mathrm{br} /$ scielo.php?script=sci_arttext $\&$ pid=S0034-73292002000100008>. Acesso em:15 maio 2017.

\footnotetext{
$53 \quad$ Ainda há resistência, como aponta PIOVESAN, dos Estados em conceber um instrumento internacional que estabeleça deveres de aceitar a idéia de permanência forçada do estrangeiro no território nacional. Essa resistência pode ser vislumbrada na dificuldade de aprovação da Convenção sobre Asilo Territorial de 1977, que ainda náo obteve adesão dos países. PIOVESAN, F. __ . O direito de asilo e a proteção internacional dos refugiados. In: ARAÚJO, N. de; ALMEIDA, G. A. (coords.) O Direito Internacional dos Refugiados: uma perspectiva brasileira. Rio de Janeiro: Renovar, 2001. p. 52-53.
} 
AZEVEDO, T. P. de. Direito internacional penal e a proteçáo dos direitos humanos. Porto Alegre: Dom Quixote, 2013.

BATISTA, V. de O. Uniáo Européia: Livre circulaçáo de pessoas e Direito de Asilo. Belo Horizonte: Del Rey, 1997.

BARATTA, A. Criminologia crítica e crítica ao direito penal: introduçáo à sociologia do direito penal. Trad. Juarez Cirino dos Santos. 3a . ed. Rio de Janeiro: Editora Revan, 2002.

BARRETO, L. P. F. T. Das diferenças entre os institutos jurídicos do asilo e do refúgio. Disponível em: <www.migrante.org.br/Asilo\%20e\%20Refugio\%20diferencas. doc> Acesso em: 28 de mar. de 2017.

CAPUTO BASTOS, C. E. e GARCIA, M. Judiciário pode rever decisão que deu refúgio a Battisti. Revista Consultor Jurídico. Conjur, 10/03/2009. Disponível em:<http://www. conjur.com.br/2009-mar-10/judiciario-rever-decisao-ministerial-deu-refugio-battisti $>$. Acesso em: 15 maio 2017.

CASELLA, P. B. Refugiados: conceito e extensão. In: ARAÚJO, N. de; ALMEIDA, G. A. (coords.) O Direito Internacional dos Refugiados: uma perspectiva brasileira. Rio de Janeiro: Renovar, 2001, p.17-26.

DEL'OMO, F. de S. Curso de Direito Internacional Público. 2a ed. Rio de Janeiro: Forense, 2006.

FOUCAULT, M. A verdade e as formas jurídicas. Rio de Janeiro: NAU Editora, 2005.

GEDIEL, J. A. Refúgio e hospitalidade. Curitiba: Kairós, 2016.

GOMES, L. F. Estupro e atentado violento ao pudor simples sáo crimes hediondos? In: www.ibccrim.com.br. Acesso em: 10 maio 2017.

. Mídia e Direito Penal. Revista Jus Navigandi, Teresina, ano 14, n. 2040, 31 jan. 2009. Disponível em: <https://jus.com.br/artigos/12274>. Acesso em: 10 maio 2017.

HAYDU, M. O envolvimento do Brasil com a problemática dos refugiados: um breve histórico. Revista Ponto-e-Vírgula, no 6, PUC-São Paulo, p. 183-200, 2009/2.

JAEGER, G. On the History of the International Protection of Refugees. International Review of the Red Cross, vol. 83, no. 843. Setembro 2001. Disponível em: https://www. icrc.org/ara/assets/files/other/727_738_jaeger.pdf. Acesso em 10 maio 2017.

JO, H. M. Introduçáa ao Direito Internacional. 2. ed. São Paulo: LTr, 2004.

JUBILUT, L. L. O Direito Internacional dos Refugiados e sua Aplicaçáo no Ordenamento Jurídico Brasileiro. São Paulo: Método, 2007. 
. O procedimento de Concessão de Refúgio no Brasil. Disponível em: <www.mj.gov. br/services/.../FileDownload.EZTSvc.asp?> Acesso em: 20 de mar. de 2017.

LAUTERPACHT, S. E.; BETHLEHEM, D.The scope and content of the principle of non-refoulement: Opinion. In: UN High Commissioner for Refugees (UNHCR). Global Consultations on International Protection/Second Track], 20 June 2001. Disponível em http://www.refworld.org/docid/3b3702b15.html. Acesso em 10 maio 2017.

LEÂO, R. Z. R. A temática do Refúgio no Brasil após a Criação do Conare. In: MILESI, Rosita. (org.) Refugiados: Realidade e Perspectivas. São Paulo: Loyola/IMDG/CSEM, 2003. p. 173-96.

LUZ FILHO, J. F. S. Non-refoulement: breves consideraçóes sobre o limite jurídico à saída compulsória do refugiado. In: ARAÚJO, N. de; ALMEIDA, G. A. de. (coords.) O Direito Internacional dos Refugiados: uma perspectiva brasileira. Rio de Janeiro: Renovar, 2001. p. 177-210.

MARCOLINI, A. As perspectivas para os Refugiados no Século XXI. In: MILESE, Rosita. (org.) Refugiados: Realidade e Perspectivas. São Paulo: Loyola/IMDG/CSEM, 2003. p. 197-210.

MAZZUOLI, V.; MARINONI, L. G. Controle de Convencionalidade. Brasília: Gazeta Jurídica, 2013.

MORAES, A. R. A. de. A terceira velocidade do direito penal: o "direito penal do inimigo". 2006. Dissertaçấo (Mestrado).

MORAES, T. G. A. de. O papel do Judiciário na proteção dos refugiados. Revista da Faculdade de Direito: Universidade Federal do Rio Grande do Sul. Volume Especial Jan. 2014,. - Porto Alegre: Faculdade de Direito/UFRGS, 2014, p. 164-181.

PONTE NETO, C. F. da. Reassentamento de Refugiados no Brasil. In: MILESI, R. (org.) Refugiados: Realidade e Perspectivas. São Paulo: Loyola/IMDG/CSEM, 2003. p. $155-71$.

PIOVESAN, F. Direitos Humanos e Justiça Internacional. Saraiva: São Paulo, 2006. 2007.

Direitos Humanos e Direito Constitucional Internacional. Saraiva: São Paulo, . O direito de asilo e a proteçáo internacional dos refugiados. In: ARAÚJO, N. de; ALMEIDA, G. A. (coords.) O Direito Internacional dos Refugiados: uma perspectiva brasileira. Rio de Janeiro: Renovar, 2001. p.27-64.

PITA, A. C. Direitos Humanos e Asilo. In: MILESE, R. (org.) Refugiados: Realidade e Perspectivas. São Paulo: Loyola/IMDG/CSEM, 2003, p. 85-98.

RAMOS, A. de C. Curso de Direitos Humanos. 3. Ed. São Paulo: Saraiva, 2016. 
RESEK, F. Direito Internacional Público. 11. ed. São Paulo: Saraiva, 2008.

ROUSSEAU, J. J. (Trad. Rolando Roque da Silva). Do contrato social. VirtualBooks. Formato: e-book/rb, ed. eletrônica: Ridendo Castigat Mores, 2002.

ROXIN, C. Política criminal e sistema jurídico penal. Trad. Luís Greco. Rio de Janeiro: Renovar, 2000.

SARMENTO, D. A ponderação de interesses na constituição federal. Rio de Janeiro: Lúmen Júris, 2003.

SOARES, G. Direitos Humanos, Direitos dos Refugiados e Direito Humanitário. Disponível em: <http://www.leonildocorrea.adv.br/curso/guido1.htm> Acesso em: 28 de mar. de 2017.

TRINDADADE, A. A. C. A Proteção Internacional dos Direitos Humanos e o Brasil. 2a Ed. Brasília: Ed: Universidade de Brasília, 2000.

- Reflexiones sobre el desarraigo como problema de Derechos Humanos frente a la conciencia Jurídica Universa. In: TRINDADE, A. A. C. e SANTIAGO, J. R. de. La nueva dimension de las necessidades de protección del ser humano en el início del siglo XXI. 2. Ed. San José, C.R.: Impresora Gossestra Internacional, 2002, p. 21-81.

TOURINHO FILHO, F. da C. Processo Penal, v. 3. Saraiva, 2014. 